\title{
Occurrence and characterisation of calcium oxalate crystals in stems and fruits of Hylocereus costaricensis and Selenicereus megalanthus (Cactaceae: Hylocereeae)
}

\author{
María Viñas $^{\mathrm{a}, 1}$, Víctor M. Jiménez ${ }^{\mathrm{a}, \mathrm{b}, *}$ \\ a CIGRAS and CIEMic, Universidad de Costa Rica, 2060 San Pedro, Costa Rica \\ ${ }^{\mathrm{b}}$ Food Security Center, University of Hohenheim, 70599 Stuttgart, Germany
}

\section{A R T I C L E I N F O}

\section{Article history:}

Received 26 May 2016

Received in revised form 6 July 2016

Accepted 11 July 2016

Available online 12 July 2016

\section{Keywords:}

Calcium oxalate crystal

Elemental composition

Energy-dispersive X-ray spectroscopy

Pitahaya

Scanning electron microscopy

X-ray powder diffraction

\begin{abstract}
A B S T R A C T
Detailed description about occurrence of calcium oxalate ( $\mathrm{CaOx}$ ) crystals in the edible vine cactus species Hylocereus costaricensis and Selenicereus megalanthus is scarce. Therefore, we evaluated and characterized the presence, morphology and composition of $\mathrm{CaOx}$ crystals in both species. Crystals were isolated from greenhouse and in vitro vegetative stems, and from ripe fruit peels and pulp by enzymatic digestion and density centrifugation and quantified with a haemocytometer. Morphologies were studied using scanning electron microscopy, elemental composition with energy-dispersive X-ray spectroscopy and salt composition with X-ray powder diffraction. Analyses conducted confirmed that isolated crystals were exclusively composed by $\mathrm{CaOx}$, both mono- and dihydrated. Highest crystal contents were measured in greenhouse stems, followed by the fruit peels. While very few crystals were quantified in in vitro plants, they were not detected in the fruit pulp at all, which is of advantage for its human consumption and could be linked to mechanisms of seed dispersal through animals. Different crystal morphologies were observed, sometimes varying between genotypes and tissues analysed. This is the first work known to the authors with a detailed characterization of $\mathrm{CaOx}$ crystals in vine cacti.
\end{abstract}

(c) 2016 Elsevier Ltd. All rights reserved.

\section{Introduction}

Calcium oxalate ( $\mathrm{CaOx}$ ) crystals are widely distributed among photosynthetic organisms (Nakata, 2003; Franceschi and Nakata, 2005). These crystals are formed from the reaction between oxalic acid $\left(\mathrm{C}_{2} \mathrm{H}_{2} \mathrm{O}_{4}\right)$, endogenously produced by the plant, with calcium taken from the environment (Franceschi and Nakata, 2005). It has been proposed that their functions could be related to calcium regulation in the tissues, protection against herbivory and detoxification of heavy metals (Finley, 1999; Korth et al., 2006; Singer et al., 2008).

Both intracellular and extracellular deposits of $\mathrm{CaOx}$ crystals have been observed in plants (Hartl et al., 2007). Intracellular deposits are generally located in the vacuoles of highly specialized cells called idioblasts, while extracellular deposits are situated in the cell wall. Distribution usually does not follow specific patterns,

\footnotetext{
* Corresponding author at: CIGRAS and CIEMic, Universidad de Costa Rica, 2060 San Pedro, Costa Rica.

E-mail addresses: mavime7@gmail.com (M. Viñas),victor.jimenez@ucr.ac.cr (V.M. Jiménez).

1 Present address: Molecular Phytopathology and Mycotoxin Research, GeorgAugust-University Göttingen, Grisebachstrasse 6, 37077 Göttingen, Germany
}

and crystals may be present in single or multiple tissues, of vegetative, reproductive, storage and even developing organs, and in photosynthetic and non-photosynthetic tissues as well (Franceschi and Nakata, 2005).

Isolation of $\mathrm{CaOx}$ crystals from plant tissues for further analysis can be a difficult task that sometimes involves several steps of blending and tissue maceration followed by manual collection with help of light microscopy (Bouropoulos et al., 2001; FraustoReyes et al., 2014; Hartl et al., 2007; Monje and Baran, 2002; Webb et al., 1995). These processes can cause crystal damage and usually the smallest crystals cannot be characterized. Improved methods to extract intact $\mathrm{CaOx}$ crystals, including the small ones, are therefore still needed.

In plants, two hydration states of $\mathrm{CaOx}$ crystals can be found: CaOx monohydrate (COM), known as Whewellite, and CaOx dihydrate (COD), named Weddellite (Nakata, 2003). A good correlation between hydration state and morphology of the crystals has been observed (Frey-Wyssling, 1981; Hartl et al., 2007; Monje and Baran, 2002), although some exceptions have also been reported (Franceschi and Nakata, 2005).

Cactaceae plants are known for accumulating large quantities of $\mathrm{CaOx}$ crystals, widely distributed in most species within the family 
(Monje and Baran, 2002). Hartl et al. (2007) found CaOx crystals in 245 of 251 Cactaceae species analysed. Related taxa tend to have similar crystallization patterns (morphology, concentration and location) of $\mathrm{CaOx}$ and, therefore, these crystals have been proposed as taxonomic criteria within Cactaceae (Monje and Baran, 2002; Hartl et al., 2007). However, some parameters, such as temperature, pressure and ion concentration, can affect crystal patterns (Franceschi and Horner, 1980).

Some species in the closely related genera of Neotropical climbing cacti, Hylocereus and Selenicereus, known as red and yellow pitahayas, respectively, have edible fruits, increasingly consumed in an emerging market (Le Bellec et al., 2006; Mizrahi et al., 2002). Red pitahayas have also potential in the food industry as a source of natural pigments due to their high contents of betalains (Esquivel et al., 2007a; Stintzing and Carle, 2007; Esquivel, 2016). Presence of $\mathrm{CaOx}$ crystals has been reported in stems in these two genera (Hartl et al., 2007); however, there is no further characterization of these crystals (especially in the edible parts of these plants).

Therefore, the aim of the present study was to characterize and evaluate the presence, morphology and composition of $\mathrm{CaOx}$ crystals in greenhouse and in vitro stems, and in fruits of Hylocereus costaricensis (F.A.C. Weber) Britton \& Rose and Selenicereus megalanthus (K. Schumann ex Vaupel) Moran.

\section{Materials and methods}

\subsection{Plant material and sample initial preparation}

Newly developed stems from greenhouse and in vitro plants, as well as peels and pulp of ripe fruits, of Hylocereus costaricensis' genotypes "Orejona" and "San Ignacio" and of Selenicereus megalanthus, were used for the analyses.

The greenhouse young stem sections (10-12 cm long) were obtained from two-year-old plants, established from field-plant cuttings. These cuttings were obtained from adult plants growing organically in Barranca, Puntarenas, Costa Rica (N 9 57.566'; W $84^{\circ} 43.217^{\prime}$ ). Each stem section was washed with brush, water and domestic detergent. The distal and the basal parts of each stem section were discarded, leaving only the middle segment, to which the thorns and epidermis were subsequently removed with scalpel. Finally, this middle part was sectioned in small segments of about $1-2 \mathrm{~mm}^{3}$.

For the in vitro samples, $2-3 \mathrm{~cm}$ long plants, obtained from in-vitro-germinated seeds (from fruits of the same plants used for obtaining the cuttings) and subcultured every 4-6 weeks on Murashige and Skoog (1962) medium devoid of plant growth regulators for at least two years [photoperiod of $12 \mathrm{~h}$ $\left(10.2-20.5 \mu \mathrm{mol} \mathrm{m}^{-2} \mathrm{~s}^{-1}\right.$, Sylvania Supersaver Cool White, 32W, F48T12/CW/SS) at $24-25^{\circ} \mathrm{C}$, as in Viñas et al. (2012)], were used. The thorns were removed and the tissue was sectioned in small segments as described for greenhouse samples.

Hylocereus fruits were harvested in the same commercial plantation described above. Selenicereus fruits, labelled as of Colombian origin, were purchased in a local supermarket. Each fruit was opened and the pulp (endocarp) was manually separated from the peel (mesocarp and skin). Pulp and peels were separately sectioned in small segments as described above.

\subsection{Extraction and quantification of crystals}

Tissue maceration and release of crystals were conducted by incubating $3 \mathrm{~g}$ of each tissue (stem or fruit portion) for $5 \mathrm{~h}$ at $120 \mathrm{rpm}$ in $20 \mathrm{ml}$ Pectinase $62 \mathrm{~L}-\mathrm{P062} \mathrm{L}(10 \% \mathrm{v} / \mathrm{v})$ (Biocatalysis, Cardiff, UK. Source: Aspergillus sp.) at room temperature in the darkness (modified from Schweiggert et al., 2009), then filtered through $45 \mu \mathrm{m}$ stainless steel mesh to remove debris, and centrifuged for $9 \mathrm{~min}$ at $43 \times \mathrm{g}$. After discarding the supernatant with a Pasteur pipette, the pellet, composed by small cellular debris and crystals, was re-suspended in $3 \mathrm{ml}$ of either 40,50, 55, 60 or $65 \%(\mathrm{w} / \mathrm{v})$ sucrose solutions (the latter concentration was preheated for dissolving the sucrose and cooled to room temperature before use) and centrifuged again for $9 \mathrm{~min}$ at $43 \times \mathrm{g}$. Supernatant (containing cellular debris) was almost totally removed with a Pasteur pipette, leaving only $0.1 \mathrm{ml}$ of solution with crystals and some cellular debris in the bottom of the centrifuge tube, which was subsequently washed twice with $3 \mathrm{ml}$ distilled water and the same centrifugation cycles described above. After the last wash, crystals were re-suspended in $0.5 \mathrm{ml}$ distilled water.

For crystal quantification, one drop of the previous suspension was placed in a Fuchs-Rosenthal haemocytometer (Thomas Scientific, Horsham, PA, USA) and crystals were counted with a light microscope (100x) (Reichert-Jung, series 150, NY, USA). Crystal amount was calculated as follows:

$$
\begin{aligned}
& \text { Crystals } \mathrm{ml}^{-1} \\
& \quad=\text { number of crystals }(40 \times, 0.025 \mathrm{~mm} \text { field of view }) * 5000
\end{aligned}
$$

$$
\begin{aligned}
& \text { Crystals } \mathrm{g}^{-1} \\
& \quad=\text { crystals } \mathrm{ml}^{-1} * \text { final volume }(\mathrm{ml}) * \text { grams of fresh tissue }^{-1}
\end{aligned}
$$

The rest of the solution with crystals was stored at $-20^{\circ} \mathrm{C}$ for further analyses.

\subsection{Crystal in situ quantification}

Quantification of crystals directly in the tissues was performed with fresh material using three randomly selected shoots of each greenhouse genotype (identical to those used for crystal extraction). Two samples (of approximately $1 \mathrm{~cm}^{2}$ ) of mesophyll tissue of each shoot were taken. Thin sections were prepared by serial free hand sectioning of each sample by razor and immediately mounted on slides and observed under the light microscope $(40 \times)$ (Carl Zeiss, Axio Vert. A1, Göttingen, Germany). The number of crystals per mesophyll cell was calculated by counting the number of crystals in 20 randomly selected cells per shoot per genotype. The percentage of cells with crystals was calculated by counting the number of cells that had crystals of a total of 100 randomly-selected mesophyll cell observations per shoot per genotype.

\subsection{Crystal morphology and composition}

One drop $(0.1 \mathrm{ml})$ of the crystal suspension was mounted with silver paint in a strip of double-sided carbon tape attached to a $15 \mathrm{~mm}$ scanning electron microscope (SEM) stub. The stubs with the samples were then dried at $50^{\circ} \mathrm{C}$ for $30 \mathrm{~min}$. The samples were subsequently coated with $40 \mathrm{~nm} \mathrm{Au} / \mathrm{Pd}$ layers using an IB-3 ion coater (Giko, Tokyo, Japan) and the morphology observed with a S-570 SEM (Hitachi, Tokyo, Japan) working at $15 \mathrm{kV}$. Crystal shape and type (COM or COD) were tentatively assigned according to Frey-Wyssling (1981), Pennisi et al. (2001) and Hartl et al. (2007).

Elemental spectra of crystals were analysed by mounting samples (extracted crystals) on $30 \mathrm{~mm}$ SEM stubs as described above, but without the ion coating, and by using an energy-dispersive X-ray (EDX) analyser (Advanced Analysis Technologies, Dane, WI, USA), attached to the S-570 SEM. Accelerating voltage of $20 \mathrm{kV}$ and analysis time of $60 \mathrm{~s}$ were routinely used.

Crystal salt composition was determined in lyophilized and macerated tissues with X-ray powder diffraction. A Bruker D8 
Table 1

Amount of crystals isolated through enzymatic digestion and density separation from the tissues and genotypes of pitahaya evaluated.

\begin{tabular}{lll}
\hline Tissue & Genotype & Crystals $\mathrm{g}^{-1}\left(\times 10^{6}\right)^{*}$ \\
\hline Greenhouse stems & H. costaricensis 'San Ignacio' & $11.70 \mathrm{~b}$ \\
& H. costaricensis 'Orejona' & $10.41 \mathrm{~b}$ \\
& S. megalanthus & $31.83 \mathrm{a}$ \\
Fruit peels & H. costaricensis 'San Ignacio' & $2.58 \mathrm{~d}$ \\
& H. costaricensis 'Orejona' & $2.21 \mathrm{~cd}$ \\
S. megalanthus & $6.26 \mathrm{bc}$ \\
In vitro shoots & H. costaricensis 'San Ignacio' & $0.02 \mathrm{f}$ \\
& H. costaricensis 'Orejona' & $0.04 \mathrm{ef}$ \\
& S. megalanthus & $0.11 \mathrm{e}$ \\
\hline
\end{tabular}

* Values followed by the same letter are not significantly different at the $\mathrm{p} \leq 0.05$ level, according to LSD test.

Advance diffractometer (Bruker AXS, Karlsruhe, Germany) operating with $\mathrm{CuK} \alpha 1-\mathrm{K} \alpha 2$ in Bragg Bentano configuration was used at $45 \mathrm{kV}$ and $30 \mathrm{~mA}$. Scans from $2 \theta 10^{\circ}$ to $44^{\circ}$ with a step width of 0.019 and an equivalent speed of $501 \mathrm{~s}$ were performed. ICDD PDF-2 2007 database was used to identify the crystalline materials.

\subsection{Data analysis}

Crystal amount (crystals $\mathrm{g}^{-1}$ ) was analysed with factorial (tissue vs. genotype) analysis of variance (ANOVA) in four biological replicates, while number of crystals per cell was analysed with one-way ANOVA in sixty replicates (20 randomly selected cells per shoot). In very case, Fisher LSD test was subsequently used for mean comparison using Statistica 6.0 (StatSoft Inc., Tulsa, Oklahoma, USA). The percentage of cells with crystals was evaluated as presence or absence (frequencies), by chi-square analysis using Infostat statistical program, version 2008 (Universidad Nacional de Córdoba, Córdoba, Argentina).

\section{Results}

\subsection{Extraction and quantification of crystals}

After enzymatic digestion, complete disintegration of the tissues was observed in all samples under the digesting conditions tested. Subsequent separation of crystals from tissue remnants by density centrifugation was based on protocols for protoplast purification. In this case, $65 \%$ sucrose showed qualitatively best results for the separation of debris from the crystals through flotation of the former. This procedure allowed suitable isolation and separation of the crystals, facilitating their quantification and producing clean EDX spectra, as can be seen below.

Crystals were observed in varying quantities in the vegetative stems of in vitro and greenhouse plants, as well as in the fruit peels, in all analysed genotypes. Greenhouse-developed stems from all genotypes showed the highest crystal quantity (more than $1 \times 10^{7}$ crystals $\mathrm{g}^{-1}$ ), followed by the fruit peels of $S$. megalanthus (Table 1 ). The fruit peels of both $H$. costaricensis genotypes had lower contents (about $2 \times 10^{6}$ crystals $\mathrm{g}^{-1}$ ), while the lowest values were found in the shoots from in vitro-cultured plants (with $0.2-1.1 \times 10^{5}$ crystals $\mathrm{g}^{-1}$ ). No crystal could be found in the pulp (fruit endocarp) in any of the genotypes evaluated.

The two Hylocereus genotypes evaluated ("San Ignacio" and "Orejona") did not differ in the crystal quantity in any of the tissues analysed, which were about one third of the one measured in S. megalanthus (Table 1).
Table 2

Number of crystals per mesophyll cell and percentage of cells with crystals quantified in situ in greenhouse shoots of the pitahaya genotypes evaluated.

\begin{tabular}{lll}
\hline Genotype & $\begin{array}{l}\text { Number of } \\
\text { crystals per cell }\end{array}$ & $\begin{array}{l}\text { Cells with } \\
\text { crystals }(\%)^{* *}\end{array}$ \\
\hline H. costaricensis 'San Ignacio' & $5.3 \mathrm{c}$ & $40.8 \mathrm{c}$ \\
H. costaricensis 'Orejona' & $9.2 \mathrm{~b}$ & $51.3 \mathrm{~b}$ \\
S. megalanthus & $11.7 \mathrm{a}$ & $63.7 \mathrm{a}$ \\
\hline${ }^{*}$ Values followed by the same letter are not significantly different at the $\mathrm{p} \leq 0.05$ \\
level, according to LSD test. \\
${ }_{* *}$ Values followed by the same letter are not significantly different at the $\mathrm{p} \leq 0.05$, \\
according to Chi-square analysis.
\end{tabular}

\subsection{Crystal in situ quantification}

Number of crystals per mesophyll cell and percentage of cells with crystals were higher in S. megalanthus shoots than in the Hylocereus genotypes (Table 2). Similarly, the $S$. megalanthus tissues showed the highest amount of crystals when enzymatic extraction was performed (Table 1); however, without differences between "Orejona" and "San Ignacio".

\subsection{Crystal morphology and composition}

Five basic shapes (forms) were observed in greenhouse young vegetative stems and in the fruit peels (Fig. 1, Table 3). Due to the low number of crystals present in the in vitro plants, it was not possible to characterize them further. Raphides were the largest crystals observed, some of them reaching a size of approximately 60-70 $\mu \mathrm{m}$. They were, together with styloids, stick-shaped crystals, typically $1-2 \mu \mathrm{m}$ thick. The smallest crystals $(<10 \mu \mathrm{m})$ were the bipyramids followed by the tetragonal prisms.

The five crystal forms were observed only simultaneously in the vegetative stems of the $H$. costaricensis cv. "San Ignacio" greenhouse plants. All other samples showed less crystal diversity. For example, no tetragonal prisms were observed in "Orejona" greenhouse stems, while neither tetragonal prisms nor bipyramids could be detected in S. megalanthus greenhouse stems. In the fruit peels, only monoclinic styloids were found in all genotypes, while rhomboidshaped pinacoids were not found in yellow pitahaya peels and neither raphides nor tetragonal prisms were observed in the red pitahaya genotype "San Ignacio". Remarkably, bipyramids were not detected in the fruit peels of any of the genotypes studied (Table 3).

Crystals of both hydration forms [COM and COD, tentatively assigned considering their morphology according to Frey-Wyssling (1981), Pennisi et al. (2001) and Hartl et al. (2007)] were observed in both Hylocereus genotypes evaluated (Table 3 ).

EDX analysis showed that the crystals contained $\mathrm{C}, \mathrm{O}$ and Ca without major evidence of additional minor elements. Fig. 2 presents one of the spectra obtained; this pattern was similar in all crystals and genotypes analysed. In addition, X-ray diffraction patterns confirm simultaneous occurrence of Whewellite (COM) and Weddellite (COD) crystals in Hylocereus costaricensis and Selenicereus megalanthus greenhouse stem segments (Fig. 3). Noteworthy, although electron micrographs did not reveal the presence of typical morphologies of COD crystals in the stems of S. megalanthus, (Table 3), X-ray diffraction patterns confirm their presence (Fig. 3C). No particular crystal morphology pattern could be specifically established for any individual genotype.

\section{Discussion}

\subsection{Extraction and quantification of crystals}

In this paper we describe a gentle protocol to extract and purify CaOx crystals from tissues of two economically important cactus 


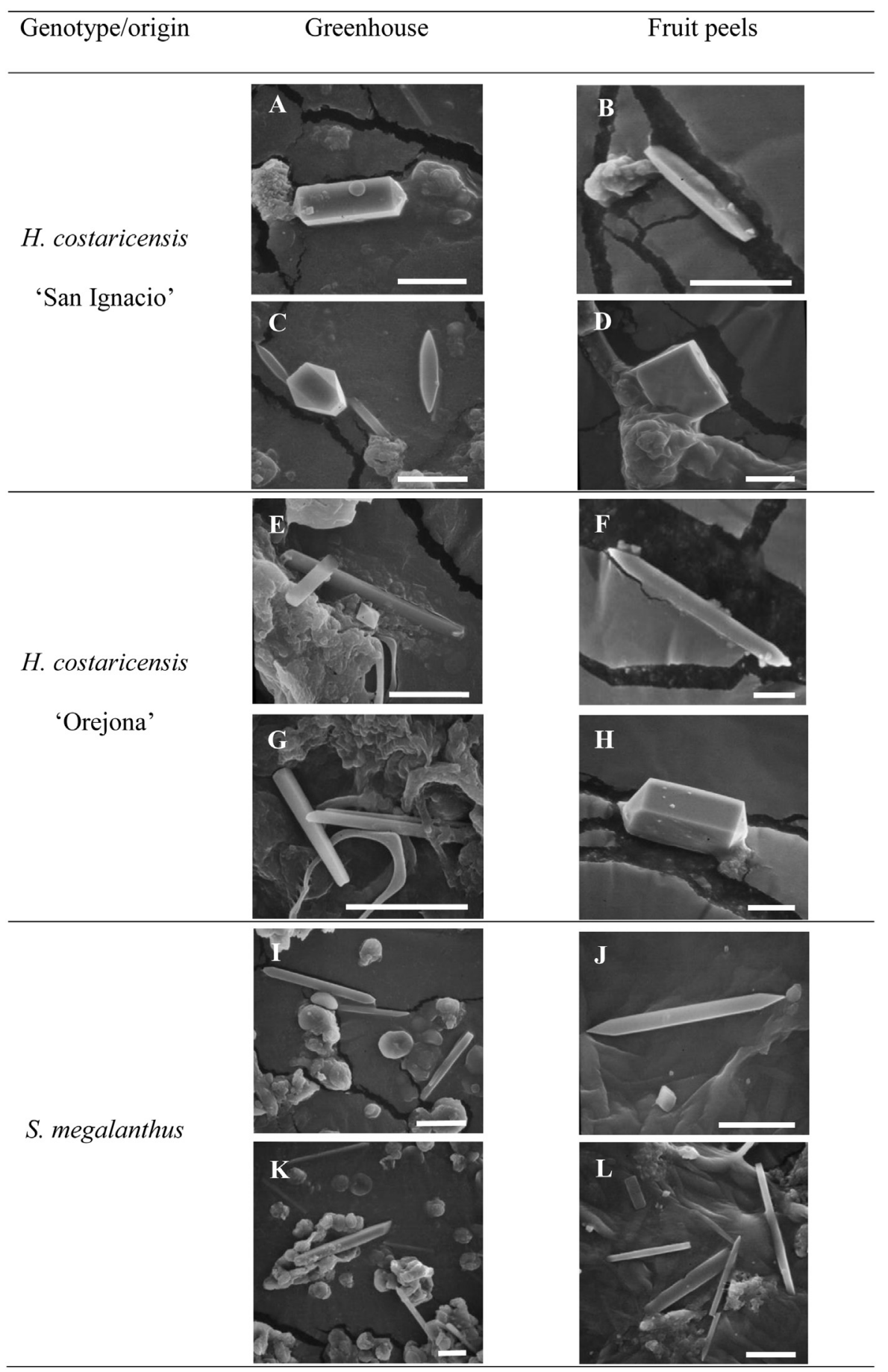

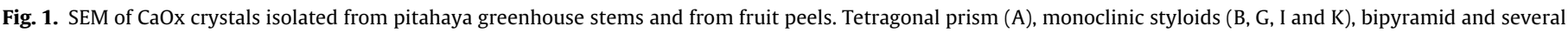
styloids (C), rhomboid (D), very small bipyramid, one large styloid and a developing styloid (E), raphides $(\mathrm{F}, \mathrm{J}$ and $\mathrm{L})$ and tetragonal prism $(\mathrm{H})$. Bar $=10 \mu \mathrm{m}$.

species, Hylocereus and Selenicereus, based on combining pectinase digestion [a process developed for liquefaction of red pitahaya pulp by Schweiggert et al. (2009)], with sucrose density centrifugation, as used in our lab to purify protoplasts from cell and tissue debris after digesting the cell wall. This protocol, tailored to succulent plants with a mucilaginous matrix, joins others involving tissue maceration, followed by filtering and manual collection via swirling in a spot plate. Our approach is less laborious and time consuming than others based on manual collection under a dissecting light microscope, followed by several washes with water or ethanol, and allows recovery of very small crystals, which cannot be easily achieved with manual collection. In addition, avoiding mechanical blending of the tissues reduces damage to the crystals, which, although not very frequent, was reported earlier (Hartl et al., 2007). Although enzymatic tissue digestion for isolation of CaOx crystals has been successfully employed in other plant species (Ilarslan et al., 1997; Monje and Baran, 1996), differences in the matrix composition, mainly polysaccharides, might force testing the best option for individual cases. Pectinase has probably worked in this case because of the high pectin contents of pitahaya tissues (Esquivel et al., 2007b; García-Cruz et al., 2013; Ramírez-Truque et al., 2011; Tang et al., 2011). 
Table 3

Distribution of crystal shapes by tissue and genotype.

\begin{tabular}{|c|c|c|c|c|c|}
\hline Genotype & Monoclinic styloid & Rhomboid-shaped pinacoid & Raphide & Tetragonal prism & Bipyramid \\
\hline \multicolumn{6}{|l|}{ Greenhouse stems (\%) } \\
\hline H. costaricensis 'San Ignacio' & 26.9 & 19.2 & 15.4 & 23.1 & 15.4 \\
\hline H. costaricensis ‘Orejona’ & 42.9 & 7.1 & 21.4 & 0 & 28.6 \\
\hline S. megalanthus & 33.3 & 16.7 & 50 & 0 & 0 \\
\hline \multicolumn{6}{|l|}{ Fruit peels (\%) } \\
\hline H. costaricensis 'San Ignacio' & 33.3 & 66.7 & 0 & 0 & 0 \\
\hline H. costaricensis 'Orejona' & 37.5 & 12.5 & 25 & 25 & 0 \\
\hline S. megalanthus & 57.1 & 0 & 28.6 & 14.3 & 0 \\
\hline Hydration state ${ }^{* *}$ & $\mathrm{COM}$ & $\mathrm{COM}$ & $\mathrm{COM}$ & COD & COD \\
\hline
\end{tabular}

* Number of times each crystal shape was observed in relation to total observations (approximately 10 under electron microscope) performed in 5-6 locations of a single sample and with three biological replicates for each genotype.

** According to Frey-Wyssling (1981), Pennisi et al. (2001) and Hartl et al. (2007).

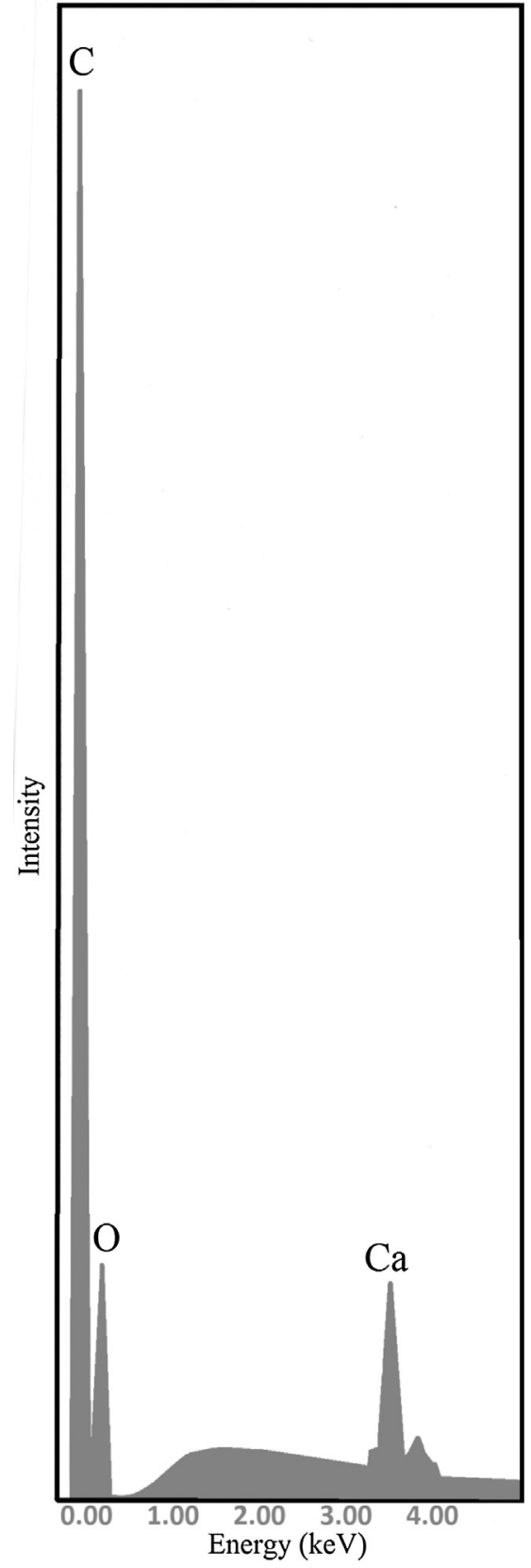

Fig. 2. EDX analysis of crystals extracted from greenhouse stems of $H$. costaricensis 'Orejona'.

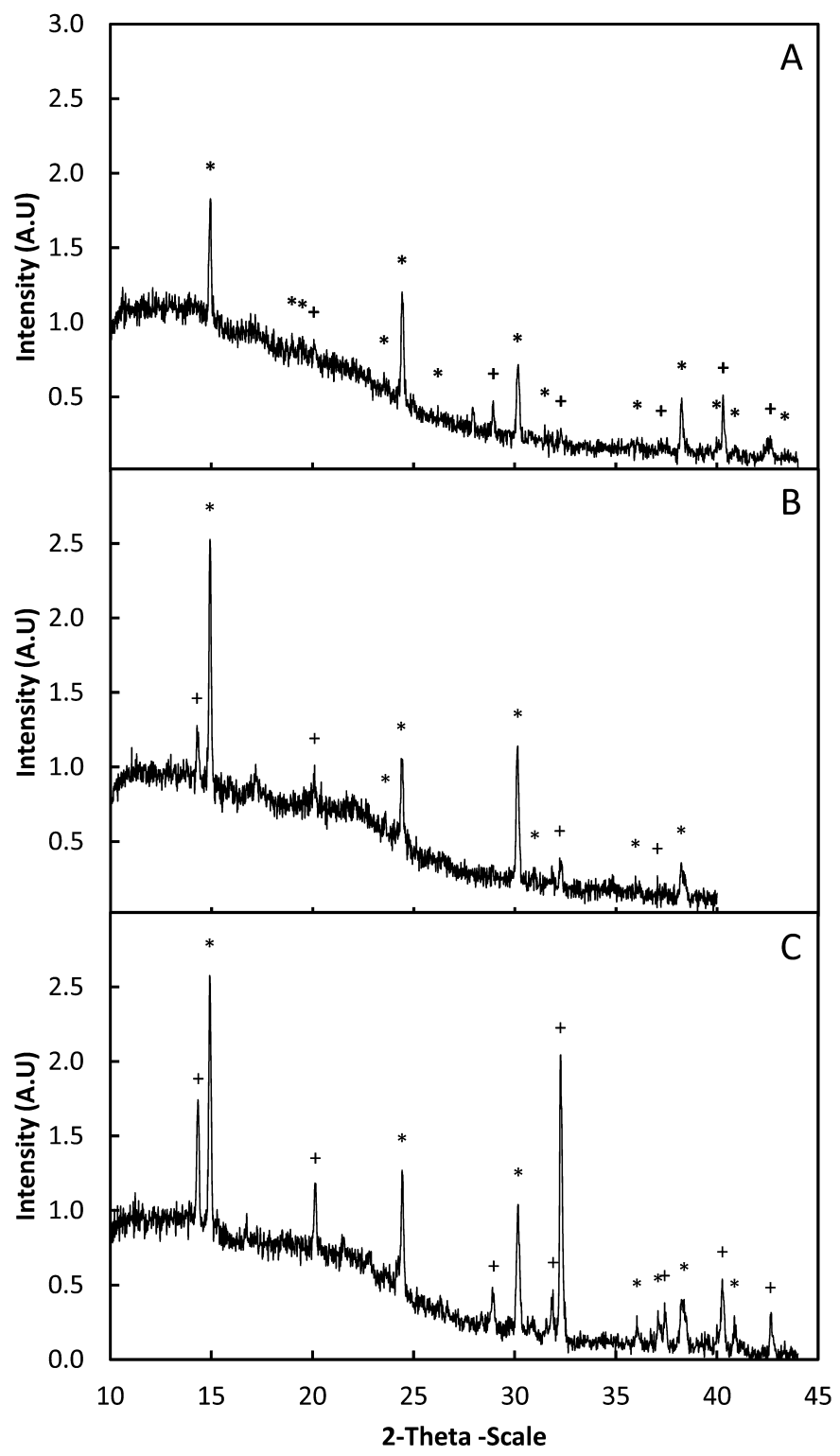

Fig. 3. X-ray diffraction pattern of crystals in lyophilized greenhouse stems of the three genotypes, outlining the characteristic peaks of Whewellite $\left({ }^{*}\right)$ and Weddellite (+). H. costaricensis 'San Ignacio' (A), H. costaricensis 'Orejona' (B) and S. megalanthus (C). 
The highest numbers of $\mathrm{CaOx}$ crystals observed in the greenhouse vegetative stems might reflect their function against herbivory as proposed elsewhere (Franceschi and Nakata, 2005; Nakata, 2003). CaOx crystals in the fruit peels might also reduce depredation of unripe fruits by animals, allowing them to fully develop, mature and then split, exposing then the fruit pulp with ripe seeds. Absence of $\mathrm{CaOx}$ crystals in the pulp has sense if pitahaya seed dispersal through animals is of any importance for these cactus species, as observed in other species within the family (Godínez-Alvarez et al., 2002; Montiel and Montaña, 2000), and is of relevance for the human consumption of these commercial important species. On the other side, lower crystal contents found in in vitro plants might be related, in addition to the above-mentioned environmental factors (temperature, pressure and ion concentration), to the low Ca uptake associated in these plants to the reduced transpiration rate caused by the high relative humidity in the culture vessels (Cassells and Walsh, 1994). Further, higher contents generally found in Selenicereus seem to confirm genetic determination of $\mathrm{CaOx}$ accumulation, as reported previously (Hartl et al., 2007).

\subsection{Crystal morphology and composition}

Previous description of CaOx crystal morphology within the tribe Hylocereeae was limited to Hartl et al. (2007). Although they did not give a detailed account of all crystal shapes found in the 245 cactus species studied, they mentioned that raphides prevailed in Hylocereus and Selenicereus stems. This was also found in our Selenicereus greenhouse stems, but varied greatly in the stems of both Hylocereus genotypes and in the fruit peels of all studied genotypes as well (Table 3). Therefore, use of CaOx crystal morphology as taxonomic criterium, as proposed by some authors (Hartl et al., 2007; Monje and Baran, 2002) needs to be carefully assessed.

EDX and X-ray diffraction analyses confirmed that the crystals found in the samples studied are composed of $\mathrm{CaOx}$ alone. This has been also found in other cactus species (Monje and Baran, 2002), although there is evidence for accumulation of $\mathrm{SiO}_{2}, \mathrm{CaCO}_{3}$ and $\alpha$-quartz in this family as well (Monje and Baran, 2000, 2004).

Our results show the presence of both hydration forms of $\mathrm{CaOx}$ in the different genotypes studied. Although some reports on accumulation of CaOx crystals in Cactaceae initially showed no co-existence of the two hydration forms in the same subfamilies (Monje and Baran, 2002), subsequent studies evidenced that both hydrates occur simultaneously in several Cactaceae taxa (even in the same plant in the particular case of Hylocereeae), which seems to be rare in other angiosperms (Hartl et al., 2007).

X-ray diffraction pattern unequivocally shows the presence of both hydration states in Selenicereus greenhouse stems (Fig. 3C). However, no COD crystals [according to the classification of Hartl et al. (2007)] were found in the same samples when the morphologies were characterized through electron microscopy (Table 3). This seems an additional argument to support that some crystal morphologies can be either COM or COD, as reviewed by Franceschi and Nakata (2005).

\section{Conclusions}

This study allowed extraction and quantification, as well as morphological and compositional characterization, of $\mathrm{CaOx}$ crystals in Hylocereus costaricensis and Selenicereus megalanthus. CaOx crystals were efficiently extracted through combination of enzymatic digestion and density centrifugation. The isolation method employed produced crystal preparations in short time, adequate for chemical and morphological evaluation. Analyses conducted confirmed they are $\mathrm{CaOx}$ crystals, both mono- and dihydrated. Highest crystal con- tents were measured in greenhouse stems, followed by fruit peels. While very few crystals were quantified in in vitro plants, they were not detected in the fruit pulp at all. Absence of CaOx crystals in the fruit pulp could be related to mechanisms of seed dispersal through animals. On the other side, higher crystal concentration in the vegetative parts might reflect their role against herbivory. Different crystal morphologies were observed, sometimes varying between genotypes and tissues analysed.

\section{Conflict of interest}

The authors declare that they have no conflict of interest.

\section{Acknowledgements}

This work was supported by the University of Costa Rica (project number VI-810-B0-176). We acknowledge scientific and technical assistance of R. Loáiciga-Chavarría and E. Sánchez (CIEMic, University of Costa Rica) and of L. Rojas and M.L. Montero (Chemistry Department, University of Costa Rica). Hylocereus fruits were kindly provided by R. Crespo.

\section{References}

Bouropoulos, N., Weiner, S., Addadi, L., 2001. Calcium oxalate crystals in tomato and tobacco plants: morphology and in vitro interactions of crystal-associated macromolecules. Chem. A Eur. J. 7, 1881-1888, http://dx.doi.org/10.1002/ 1521-3765(20010504)7:9<1881:AID-CHEM1881>3.0.CO;2-I.

Cassells, A.C., Walsh, C., 1994. The influence of gas permeability of the culture lid on calcium uptake and stomatal function in Dianthus microplants. Plant Cell. Tissue Organ Cult. 37, 171-178.

Esquivel, P., Stintzing, F.C., Carle, R., 2007a. Pigment pattern and expression of colour in fruits from different Hylocereus sp. genotypes. Innov. Food Sci. Emerg. Technol. 8, 451-457.

Esquivel, P., Stintzing, F.C., Carle, R., 2007b. Comparison of morphological and chemical fruit traits from different pitaya genotypes (Hylocereus sp.) grown in Costa Rica. J. Appl. Bot. Food Qual. 81, 7-14

Esquivel, P., 2016. Betalains. In: Carle, R., Schweiggert, R.M. (Eds.), Handbook on Natural Pigments in Food and Beverages: Industrial Applications for Improving Food Color. Woodhead Publishing pp. 81-99.

Finley, D.S., 1999. Patterns of calcium oxalate crystals in young tropical leaves: a possible role as an anti-herbivory defense. Rev. Biol. Trop. 47, 27-31.

Franceschi, V., Horner, H., 1980. Calcium oxalate crystals in plants. Bot. Rev. 46 361-427, http://dx.doi.org/10.1007/bf02860532.

Franceschi, V.R., Nakata, P.A., 2005. Calcium oxalate in plants: formation and function. Annu. Rev. Plant Biol. 56, 41-71.

Frausto-Reyes, C., Loza-Cornejo, S., Terrazas, T., Miranda-Beltran, M.D. Aparicio-Fernandez, X., Lopez-Macias, B.M., Morales-Martinez, S.E., Ortiz-Morales, M., 2014. Raman spectroscopy study of calcium oxalate extracted from cacti stems. Appl. Spectrosc. 68, 1260-1265, http://dx.doi.org/ 10.1366/14-07485.

Frey-Wyssling, A., 1981. Crystallography of the two hydrates of crystalline calcium oxalate in plants. Am. J. Bot. 68, 130-141.

García-Cruz, E.E., Rodríguez-Ramírez, J., Méndez Lagunas, L.L., Medina-Torres, L. 2013. Rheological and physical properties of spray-dried mucilage obtained from Hylocereus undatus cladodes. Carbohydr. Polym. 91, 394-402.

Godínez-Alvarez, H., Valiente-Banuet, A., Rojas-Martínez, A., 2002. The role of seed dispersers in the population dynamics of the columnar cactus Neobuxbaumia tetetzo. Ecology 83, 2617-2629, http://dx.doi.org/10.2307/3071819.

Hartl, W.P., Klapper, H., Barbier, B., Ensikat, H.J., Dronskowski, R., Müller, P., Ostendorp, G., Tye, A., Bauer, R., Barthlott, W., 2007. Diversity of calcium oxalate crystals in Cactaceae. Can. J. Bot. 85, 501-517, http://dx.doi.org/10. 1139/b07-046.

Ilarslan, H., Palmer, R.G., Imsande, J., Horner, H.T., 1997. Quantitative determination of calcium oxalate and oxalate in developing seeds of soybean (Leguminosae). Am. J. Bot. 84, 1042-1046, http://dx.doi.org/10.2307/2446147.

Korth, K.L., Doege, S.J., Park, S.-H., Goggin, F.L., Wang, Q., Gomez, S.K., Liu, G., Jia, L., Nakata, P.A., 2006. Medicago truncatula mutants demonstrate the role of plant calcium oxalate crystals as an effective defense against chewing insects. Plant Physiol. 141, 188-195, http://dx.doi.org/10.1104/pp.106.076737.

Le Bellec, F., Vaillant, F., Imbert, E., 2006. Pitahaya (Hylocereus spp.): a new fruit crop a market with a future. Fruits 61, 237-250.

Mizrahi, Y., Nerd, A., Sitrit, Y., 2002. New fruits for arid climates. In: Janick, J., Whipkey, A. (Eds.), Trends in New Crops and New Uses. ASHS Press, Alexandria, VA, pp. 378-384.

Monje, P.V., Baran, E.J., 1996. On the formation of weddellite in Chamaecereus silvestrii, a Cactaceae species from Northern Argentina. Z. Naturforsch. C 51, 426-428. 
Monje, P.V., Baran, E.J., 2000. First evidences of the bioaccumulation of $\alpha$-quartz in Cactaceae. J. Plant Physiol. 157, 457-460.

Monje, P.V., Baran, E.J., 2002. Characterization of calcium oxalates generated as biominerals in cacti. Plant Physiol. 128, 707-713, http://dx.doi.org/10.1104/pp. 010630.

Monje, P.V., Baran, E.J., 2004. Complex biomineralization pattern in Cactaceae. J. Plant Physiol. 161, 121-123.

Montiel, S., Montaña, C., 2000. Vertebrate frugivory and seed dispersal of a Chihuahuan Desert cactus. Plant Ecol. 146, 219-227, http://dx.doi.org/10.1023/ a:1009819419498.

Murashige, T., Skoog, F., 1962. A revised medium for rapid growth and bio assays with tobacco tissue cultures. Physiol. Plant. 15, 473-497.

Nakata, P.A., 2003. Advances in our understanding of calcium oxalate crystal formation and function in plants. Plant Sci. 164, 901-909.

Pennisi, S.V., McConnell, D.B., Gower, L.B., Kane, M.E., Lucansky, T., 2001. Intracellular calcium oxalate crystal structure in Dracaena sanderiana. New Phytol. 150, 111-120, http://dx.doi.org/10.1046/j.1469-8137.2001.00075.x.

Ramírez-Truque, C., Esquivel, P., Carle, R., 2011. Neutral sugar profile of cell wall polysaccharides of pitaya (Hylocereus sp.) fruits. Carbohydr. Polym. 83, 1134-1138, http://dx.doi.org/10.1016/j.carbpol.2010.09.042.

Schweiggert, R.M., Villalobos-Gutierrez, M.G., Esquivel, P., Carle, R., 2009. Development and optimization of low temperature enzyme-assisted liquefaction for the production of colouring foodstuff from purple pitaya (Hylocereus sp. [Weber] Britton \& Rose). Eur. Food Res. Technol. 230, 269-280, http://dx.doi.org/10.1007/s00217-009-1167-0.
Singer, D.M., Johnson, S.B., Catalano, J.G., Farges, F., Brown Jr., G.E., 2008. Sequestration of $\mathrm{Sr}(\mathrm{II})$ by calcium oxalate-a batch uptake study and EXAFS analysis of model compounds and reaction products. Geochim. Cosmochim. Acta 72, 5055-5069, http://dx.doi.org/10.1016/j.gca.2008.07.020.

Stintzing, F.C., Carle, R., 2007. Betalains - emerging prospects for food scientists. Trends Food Sci. Technol. 18, 514-525.

Tang, P.Y., Kek, T.S., Gan, C.Z., Hee, C.Y., Chong, C.H., Woo, K.K., 2011. Yield and some chemical properties of pectin extracted from the peels of dragon fruit [Hylocereus polyrhizus (Weber) Britton and Rose]. Philipp. Agric. Sci. 94, 307-311.

Viñas, M., Fernández-Brenes, M., Azofeifa, A., Jiménez, V.M., 2012. In vitro propagation of purple pitahaya (Hylocereus costaricensis [F.A.C. Weber] Britton \& Rose) cv. Cebra. In Vitro Cell. Dev. Biol. Plant 48, 469-477, http://dx.doi.org/ 10.1007/s11627-012-9439-y.

Webb, M.A., Cavaletto, J.M., Carpita, N.C., Lopez, L.E., Arnott, H.J., 1995. The intravacuolar organic matrix associated with calcium-oxalate crystals in leaves of Vitis. Plant J. 7, 633-648, http://dx.doi.org/10.1046/j.1365-313X.1995. 7040633.x. 